\title{
Customer Segmentation Model Research Based on Organizational Customer Life Cycle in Telecom Operator
}

\author{
Chengrong $\mathrm{Hu}^{1, \mathrm{a}}$, Huaying $\mathrm{Shu}^{2, \mathrm{~b}}$, Xinchun Qiao ${ }^{3, \mathrm{c}}$ \\ 1 101, Dorm13, Beijing University of Posts and Telecommunications, \#10 Xitucheng Road, Haidian \\ district, Beijing, China, 100876 \\ ${ }^{2}$ School of Economics and Management, Beijing University of Posts and Telecommunications, \\ Beijing, China, 100876 \\ ${ }^{3}$ PetroChina Xinjiang Oilfield Company, \#36 Yingbin Road, Karamay, Xinjiang, China, 834000 \\ achengronghu@bupt.edu.cn, bshuhy@bupt.edu.cn, c13909906308@126.com
}

Keywords: organizational customer segmentation; telecommunications industry; Customer life cycle

\begin{abstract}
As the competition between telecom operators is getting fiercer, both new market and stock of mobile communications market begin to fall, which makes organizational customers become the main competing objectives among operators. Based on the academic research results of relevant scholars and the actual situation of customer management in telecom operators, we redefined the organizational customer lifecycle. On the basis of the organizational customer hierarchical segmentation model, we put forward the corresponding segmentation variables, segmentation method and strategy plan according to the lifecycle stage of customer relationship, to maximize long-term interactive value between telecom enterprises and customers.
\end{abstract}

\section{Introduction}

In recent years, organizational customers become an important proportion in the communication market. The cooperation scale between organizations is also increasing. Organizational customers [1] not only bind a large number of individual customers one-time, but also to bring the strategic significance and demonstration effect to the enterprise as the pioneers of new business. In conclusion, the effect of reasonable customer segmentation is particularly important in expanding new markets, stabilizing stock market, enhancing the value of existing customers and reducing the service cost. At present customer segmentation method includes statistical segmentation, psychological segmentation and behavior segmentation, which are mainly suitable for the individual customer segmentation [2]. Compared with individual customer segmentation, the organizational customer segmentation has more influence factors. But the situation now is that telecom operators subdivide organizational market by evaluating the customer value simply, lacking systematic research.

Influential organizational market segmentation model include: "early organizational market segmentation model" [3], "two-step segment research" [4], "Nested-approach" [5]. Considering the characteristics of organizational customer and communication industry, Huang Yijun and $\mathrm{He}$ Jieqiao proposed segmentation variables suitable for telecom operator organizational customers based on the concept of customer value and nested-approach, consisting of customer value, demographics, operating variables, purchasing approach, situational factors and personal characteristics [6]. 


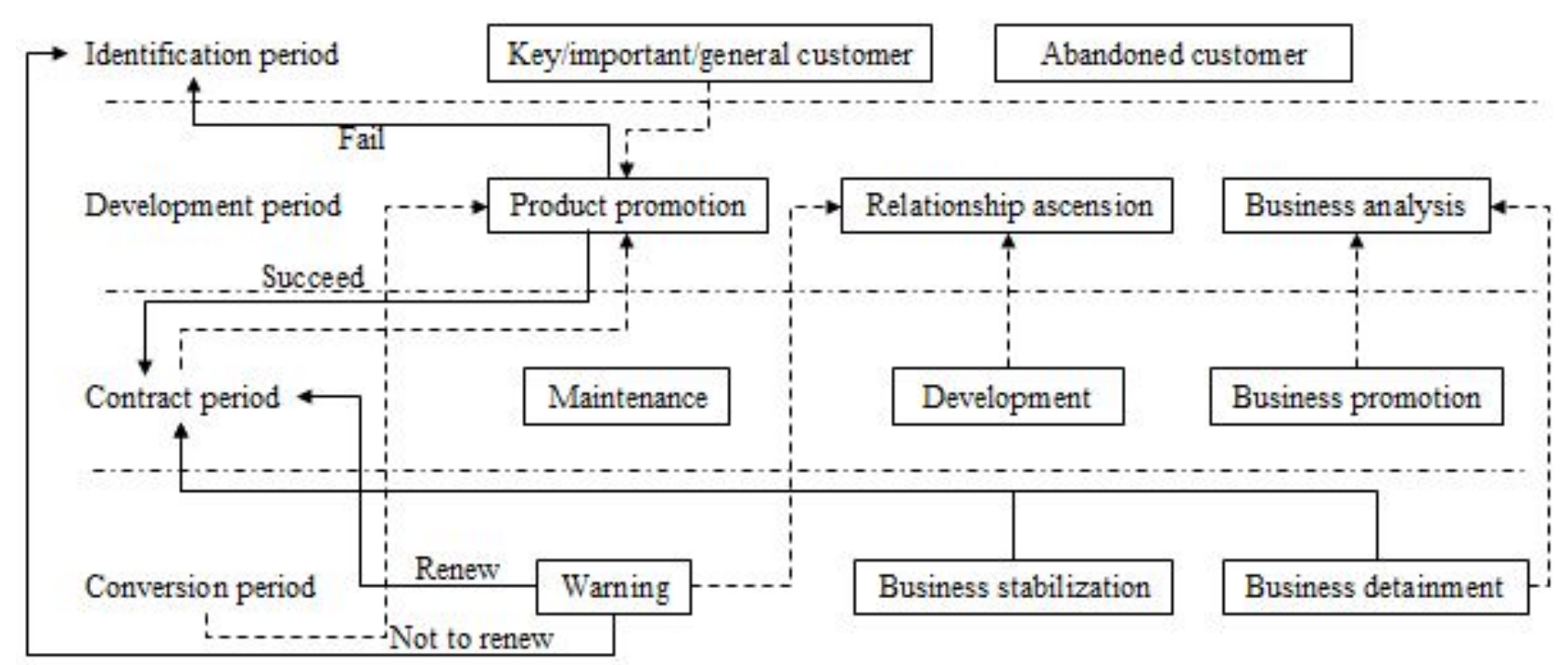

Fig. 1 Segmentation result based on organizational customer lifecycle

The effective customer relationship management should be full-course and dynamic. In customer lifecycle management, customer segmentation can help to fully grasp the behavior of customers, to track footprint in the net and to find new consumption trend early in order to make flexible customer retention policies [7]. Domestic scholar suggested that the development of customer relationship should be divided into four stages: identification, formation, stabilization and degradation [8]. However, the periodicity of customer relationship is limited and not suitable for the characteristics of communication industry and organizational customer contract. Batonda (1998) also suggested that customer relationship is affected by external environment [9], leading the phase transformation changes irregularly.

So based on these, we decided to redefine the lifecycle stage of organizational customer and to segment customer market based on nested-approach and the characteristics of lifecycle stages. The types of customers in each stage can correspond or transform to another, forming a complete and dynamic segmentation system based on organizational customer lifecycle (shown as Figure1).

\section{Stage division of organizational customer lifecycle}

Existing telecom operator organizational customers belong to contractual customers, who make specific commitments to the enterprise in certain period. Based on the characteristics of contractual customer, we divided telecom operator organizational customer lifecycle into four stages: identification, development, contract, conversion.

Identification. Customers have not signed any product contract with enterprises in this stage, where to find the target customer source.

Development. A strategy implementation stage where to establish or strengthen customer relationships and to improve customer value.

Contract. Customers have signed product contract with enterprises in this stage, where to evaluate customer relationship stability and business using, to convert towards the development period according to customer type, implementing strategy to promote relations or to add value.

Conversion. This is a key observation stage where product contracts are coming to an end that may bring loss of business or customer relationship changes. That is at least a business contract is coming to an end ( 2 months before the end of the contract period). The main task is to evaluate the expiring contract business using, then to convert towards development period to strengthen customer relationships or to retain businesses. 


\section{Customer segmentation based on organizational customer lifecycle}

According to the definition of lifecycle stage and the application of customer segmentation model, there are clear divisions among customer relationship stages and customer types. So we can judge the real-time customer relationship stage by dynamic tracking.

Identification. It is a stage that access to information of customer demand is insufficient and customer value is difficult to appear, where telecom operators usually provide mature and generic products or services according to group classifications of physical properties. Assessing potential value to reduce uncertainty is the focus in the stage. So in the nested model, variables are customer information which can be collected in the early. [10]

Table 1.Segmentation model indexes in the identification period

\begin{tabular}{c|l|l}
\hline Nested model level & Evaluation object & \multicolumn{1}{|c}{ Indexes } \\
\hline Demographics & & Customer staff size \\
$\begin{array}{c}\text { Customer value/ Potential value/ } \\
\text { Customer development potential[1] }\end{array}$ & Customer capacity & $\begin{array}{l}\text { Customer income, Customer } \\
\text { industry influence, Customer society } \\
\text { influence }\end{array}$ \\
\hline Demographics & \multirow{2}{*}{$\begin{array}{l}\text { Demand intensity } \\
\begin{array}{c}\text { Customer value/ Potential value/ } \\
\text { Customer development potential }\end{array}\end{array}$} & $\begin{array}{l}\text { Information level, Communications } \\
\text { expenditure proportion }\end{array}$ \\
\hline
\end{tabular}

In this model, the task is to analysis customers' capacity and demand. After judging the index weight by experts marking, designing index quantitative method and comprehensive evaluation, we divided organizational customers into key customer, important customers and general customer and abandoned customer. Customers of the first three types will enter into the development period to implement product promotion strategy. If customers contract business successfully, they will enter into the contract period as contractual customers, otherwise return to the identification period.

Contract. The main task of the contract period and the conversion period is to evaluate contractual customer's stability of customer relations and business using, analyzing consumption behavior [12].

Table 2.Customer relationship stability evaluation model indexes

\begin{tabular}{c|c|l}
\hline Nested model level & Primary indexes & \multicolumn{1}{|c}{ Secondary indexes } \\
\hline \multirow{4}{*}{$\begin{array}{c}\text { Customer value/ } \\
\text { Potential value }\end{array}$} & Loyalty & $\begin{array}{l}\text { Number of product using, "Share of wallet", Volatility } \\
\text { rate of total income, Cooperate time, Satisfaction, } \\
\text { Customer feedback }\end{array}$ \\
\cline { 2 - 3 } & \begin{tabular}{l} 
Credit \\
\cline { 2 - 3 }
\end{tabular} & \begin{tabular}{l} 
Arrears rate, Arrears period \\
\hline
\end{tabular} \\
\hline
\end{tabular}

Table 3.Single product using stability evaluation model indexes

\begin{tabular}{c|c|l}
\hline Nested model level & Primary indexes & \multicolumn{1}{c}{ Secondary indexes } \\
\hline \multirow{2}{*}{$\begin{array}{c}\text { Customer value/ } \\
\text { Potential value }\end{array}$} & Loyalty & $\begin{array}{l}\text { Volatility rate of product income, product using time, } \\
\text { Product satisfaction }\end{array}$ \\
\cline { 2 - 3 } & Credit & Arrears rate, Arrears period \\
\hline $\begin{array}{c}\text { Situational } \\
\text { factors[13] }\end{array}$ & Product type & Business development level \\
\cline { 2 - 3 } & Product dependence & Product usage, Product technical difficulty \\
\hline
\end{tabular}

In the contract period, we divided customers into Maintenance, Development and Business promotion three categories by evaluating the stability of customer relationship and product using.

Maintenance. Stabilities of both customer relationship and all business using are high. For the customer, we only need to carry on the business promotion of new businesses and to maintain the current customer relationship and business using.

Development. Customer relationship is not stable, whose relations preliminary build or decline. The type of customers corresponds to the relationship ascension customers in the development period, who need to be strengthened the stability of customer relationship. 
Business promotion. Though the stability of customer relationship is high, there is instable business using. The type of customers' brand loyalty is high, but the satisfaction or loyalty to one or a few products is low due to their special requirements or product problem itself. So enterprises need to analyze the business, in the development period, to strengthen the stability of product using.

Conversion. Warning. That are customers whose all businesses contract are about to expire as well as the business using is declining. If enterprises don't take customer retention strategy to improve customer relationship timely, these customers will back to the identification period after contract. So these customers need to enter into the development period, where we should analysis of customer value and measure the cost of customer retention and customer value, considering whether to implement the strategy of customer retention. If retaining successfully, customers back to the contract period after business contract renewal. Otherwise, they will get into the identification period, whose contractual relationships come to an end.

Business detainment. Not belong to warning customers, but the customers have recessionary business about to expire. Although the customer relationship will not end, that is customers still enter into the contract period after conversion period, which may lead to reduce the number of product using of these customers, whose product using also need to be analyzed in the development period.

Business stabilization. The customers will back into the contract period after the renewal, whose all the business using is stable.

Development. In the period, enterprises integrate customer information from other stages, analyzing the characteristic of customer purchase and evaluating customer value. Not only divide development strategies into product promotion, relationship ascension, business analysis three types, but to implement strategy of different intensity according to different level of customer value.

Table 4.Customer value segmentation model indexes [14-16]

\begin{tabular}{|c|c|c|}
\hline Primary indexes & Secondary indexes & 3rd-level indexes \\
\hline \multirow{2}{*}{ Current Value } & Revenue & $\begin{array}{l}\text { Information-based income, Amount of unity } \\
\text { pay, Amount of personal customer pay }\end{array}$ \\
\hline & Cost & $\begin{array}{l}\text { Service costs, Marketing costs, Customer } \\
\text { retention costs }\end{array}$ \\
\hline \multirow[b]{2}{*}{ Potential Value } & Customer relationship stability & Refer to Table 3 \\
\hline & Customer development potential & $\begin{array}{l}\text { Customer staff size, Customer income, } \\
\text { Customer industry influence, Customer } \\
\text { society influence, Information level }\end{array}$ \\
\hline
\end{tabular}

\section{Research process and data analysis}

Empirical method. We tried to put forward segmentation model variables based on the studies of many scholars in organizational customer segmentation and customer lifecycle research field and then evaluated weight and screened again based on the conclusions of in-depth interviews and questionnaire surveys with scholars from universities and executives of telecom operators' organizational customer management department. In the aspect of data analysis, we designed the measure variables of customers and products according to the characteristics of the telecom industry (shown as Table 5). On the basis of measurements, we used "Mean quantization method" [17], a kind of linear dimensionless method, and additive synthesis method to calculate comprehensive evaluation results according to the weight.

Table 5.Measure variables

\begin{tabular}{|c|c|}
\hline $\begin{array}{l}\text { Collect directly } \\
\text { - Income(total income and per product income } \\
\text { per month) } \\
\text { - Product using time } \\
\text { - Arrears rate and arrears period } \\
\text { Questionnaire survey }\end{array}$ & $\begin{array}{l}\text { - Estimated cost of strategic product } \\
\text { - Proportion of the total Information-based } \\
\text { - spending of its information-based income } \\
\text { - Established strategic partnership or not } \\
\text { - Operating income from the previous year } \\
\text { - Response to enterprise's visit or investigation }\end{array}$ \\
\hline
\end{tabular}


- Customer annual income

- Development level and Product technical difficulty rating of products(Fixed-line voice, Data, Internet, Rental network elements, ICT, Mobile service)

- Number of employees

- Information construction investment plan or number of complaints or suggestions

- Position of the industry

- Brand radiation area

- Satisfaction(to enterprise and to each product)

- Cost rating

- Product dependence (in operating management and in providing business services)

Data collection. Data can be obtained through the telecom operator's support system directly or indirectly. Data of application example come from 150 customer data selected from the Beijing Unicom list system big customer, business information and customer information acquired by questionnaire. We tried to apply the stage division of customer lifecycle and customer segmentation model mentioned above, taking 20 contractual customer data for example, named c1 to c20. $\mathrm{C} 16$ to c20 are conversion customers.

Data reduction. First we analyzed the stability of customer relationship (shown as Table 6). Table 6.Dimensionless data of customer relationship stability

\begin{tabular}{|c|c|c|c|c|c|c|c|c|}
\hline \multicolumn{2}{|r|}{ Customer samples } & $\mathrm{C} 1$ & $\mathrm{C} 2$ & C3 & $\mathrm{C} 4$ & $\mathrm{C} 5$ & \multirow{12}{*}{$\cdots$} & $\mathrm{C} 20$ \\
\hline \multirow{6}{*}{ Loyalty } & Number of product using & 0.6667 & 0.5000 & 0.3333 & 0.5000 & 0.3333 & & 0.3333 \\
\hline & Share of wallet & 0.83 & 0.54 & 0.67 & 0.76 & 0.49 & & 0.9 \\
\hline & $\begin{array}{c}\text { Volatility rate of total } \\
\text { income }\end{array}$ & 0.5833 & 0.7167 & 0.5500 & 0.9000 & 0.2833 & & 0.5500 \\
\hline & Cooperate time & 0.25 & 0.55 & 0.15 & 0.1 & 0.4 & & 0.45 \\
\hline & Satisfaction & 1 & 0.8 & 1 & 1 & 0.6 & & 0.6 \\
\hline & $\begin{array}{c}\text { Degree of customer } \\
\text { feedback }\end{array}$ & 0.4 & 0.6 & 0.6 & 1 & 0.4 & & 0.4 \\
\hline \multirow{2}{*}{ Credit } & Arrears rate & 1 & 0.75 & 1 & 1 & 0.3 & & 0.6 \\
\hline & Arrears period & 1.0000 & 0.8333 & 0.7500 & 1.000 & 0.3333 & & 0.5833 \\
\hline \multirow{2}{*}{$\begin{array}{l}\text { Strategic } \\
\text { value }\end{array}$} & $\begin{array}{l}\text { Number of strategic } \\
\text { product using, }\end{array}$ & 0.6667 & 0.3333 & 0.0000 & 0.3333 & 0.0000 & & 0.0000 \\
\hline & Strategic partnership & 1 & 0 & 0 & 0 & 0 & & 0 \\
\hline \multicolumn{2}{|c|}{ Customer relationship stability } & 0.7879 & 0.4917 & 0.3998 & 0.5594 & 0.2210 & & 0.3375 \\
\hline
\end{tabular}

The stability evaluation of single product using need concrete analysis of specific business. Taking ICT business for example, ICT business doesn't have contract deadline, whose income can be thought of no fluctuations. So we reduced the business data of customers who use ICT from c1 to 15 shown as Table 7. Data reductions of other businesses are similar to this.

Table 7.Dimensionless data of product using stability (ICT)

\begin{tabular}{|c|c|c|c|c|c|c|c|}
\hline \multirow{2}{*}{ Loyalty } & $\begin{array}{c}\text { Customer samples } \\
\text { Volility rate of product } \\
\text { income }\end{array}$ & 0.5 & 0.5 & 0.5 & 0.5 & 0.5 & 0.5 \\
\cline { 2 - 8 } Credit & Product satisfaction & 1 & 0.8 & 1 & 1 & 0.6 & 0.4 \\
\cline { 2 - 8 } & Arrears rate & 1 & 0.75 & 1 & 1 & 0 & 1 \\
\hline \multirow{2}{*}{ Product type } & $\begin{array}{c}\text { Arrears period } \\
\text { Business development } \\
\text { level }\end{array}$ & 0.6 & 0.6 & 0.6 & 0.6 & 0.6 & 0.6 \\
\hline Product & Product usage & 0.8 & 0.4 & 1 & 0.6 & 0.2 & 0.6 \\
\hline
\end{tabular}




\begin{tabular}{|c|c|c|c|c|c|c|c|}
\hline dependence & Product technical difficulty & 0.6 & 0.6 & 0.6 & 0.6 & 0.6 & 0.6 \\
\hline \multicolumn{2}{|c|}{ Product using stability } & 0.7546 & 0.5929 & 0.7771 & 0.7065 & 0.3943 & 0.6120 \\
\hline
\end{tabular}

We put forward each index's stability criteria by enterprise research and data collection preliminarily. After quantification and weighting, stability standards of customer relations and single business using are 0.48 and 0.54 approximately.

Result analysis. Through application of the stability evaluation model and customer segmentation method the article mentioned, segmentation result is shown as Table 8.

Table 8.Segmentation result based on organizational customer lifecycle

\begin{tabular}{|c|c|c|}
\hline Customer lifecycle stage & Customer type & Customer samples \\
\hline \multirow{3}{*}{ Development } & Product promotion & $\mathrm{C} 1$ to C20 \\
\cline { 2 - 3 } & Relationship ascension & $\mathrm{C} 3, \mathrm{C} 5, \mathrm{C} 6, \mathrm{C} 8, \mathrm{C} 14, \mathrm{C} 15, \mathrm{C} 19$ \\
\cline { 2 - 3 } & Business analysis & $\mathrm{C} 2, \mathrm{C} 4, \mathrm{C} 9, \mathrm{C} 10, \mathrm{C} 11, \mathrm{C} 12, \mathrm{C} 20$ \\
\hline \multirow{3}{*}{ Contract } & Maintenance & $\mathrm{C} 1, \mathrm{C} 7, \mathrm{C} 13$ \\
\cline { 2 - 3 } & Development & $\mathrm{C} 3, \mathrm{C} 5, \mathrm{C} 6, \mathrm{C} 8, \mathrm{C} 14, \mathrm{C} 15$ \\
\cline { 2 - 3 } & Business promotion & $\mathrm{C} 2, \mathrm{C} 4, \mathrm{C} 9, \mathrm{C} 10, \mathrm{C} 11, \mathrm{C} 12$ \\
\hline \multirow{3}{*}{ Conversion } & Business stabilization & $\mathrm{C} 17, \mathrm{C} 18$ \\
\cline { 2 - 3 } & Warning & $\mathrm{C} 19$ \\
\cline { 2 - 3 } & Business detainment & $\mathrm{C} 16, \mathrm{C} 20$ \\
\hline
\end{tabular}

Using the same method, we evaluated 150 customers' value by the customer value segmentation model, to divide $\mathrm{c} 1$ to $\mathrm{c} 20$ customers into $\mathrm{A}, \mathrm{B}, \mathrm{C}$ three types whose proportion is 1:2:7, representing key customer, important customers and general customer (shown as Table 9).

Table 9.Segmentation result based on customer value

\begin{tabular}{|c|c|}
\hline Customer value level & Customer samples \\
\hline A & C9, C12 \\
\hline B & C6, C10, C17 \\
\hline C & $\mathrm{C} 1, \mathrm{C} 2, \mathrm{C} 3, \mathrm{C} 4, \mathrm{C} 5, \mathrm{C} 7, \mathrm{C} 8, \mathrm{C} 11, \mathrm{C} 13, \mathrm{C} 14, \mathrm{C} 15, \mathrm{C} 16, \mathrm{C} 18, \mathrm{C} 19, \mathrm{C} 20$ \\
\hline
\end{tabular}

Clear symbols of each stage and customer type make the segmentation easy to execute. So the focus of the model application refers to selecting indexes, judging weight or stability criteria and collecting data. In the process of data collection, not all the customer data of variables can be collected, so that they need to be modified, replaced, or redesigned quantitative methods. The purpose of customer segmentation is to identify target customers with strong ability or business needs and customers who need to be improved customer relationship or extended the business requirements, and then to adopt corresponding strategic measures. The customer segmentation method based on organizational customer lifecycle with strong dynamics can response to customer behavior change quickly, realize rational resource allocation according to the customer value and reduce the risk of resource input by judging the stability of customer behavior. For multiple business customers, analyzing each business using can avoid incorrect evaluation of customer relationship result from a certain one.

\section{Summary and outlook}

We divided telecom operator organizational customer lifecycle into four stages: identification, development, contract, conversion, considering the uncertainty of organizational customer relationship, which is suitable for atypical customers. Segmentation model in the identification period helps enterprises to find target customers. In the contract period and the conversion period, customers will be evaluated the stability of customer relations and business using, and then turn into the development period where enterprise can implement strategy accord customer type and customer value. So this is a segmentation model based on the customer value and customer behavior, conducive to rational allocation of resources, reducing the risk of resource input.

However, in practice, Customer contract types are plenty, related with the functions of enterprise management departments and product types. So stage division of organizational customer lifecycle 
in the article is just a preliminary classification. Customer contract type and product characteristics need further analysis. Model indexes and stability standards still need to be adjusted according to different situations.

\section{References}

[1] LIU Rong: The Evaluation Research of Organizational Customer Value and an Empirical Study of Telecom Industry (BUPT, Beijing 2009).

[2] WU Xiaohong: Overview of Methods and Techniques of Customer Segmentation, Science \& Technology Information 1(2012), p. 110-111.

[3] Yoram Wind and Richard N. Cardozo: Industrial Market Segmentation, Industrial Marketing Management 3(1974), p. 155-166.

[4] Choffray and Cary Lilien: Industrial Marketing Segmentation by the Structure of the Purchasing Process, Industrial Marketing Management (1980).

[5] Benson P. Shapiro and Thomas V. Bonoma: How to segment industrial markets, Harvard Business Review 62(1984), p. 104-110.

[6] HE Jieqiao:A Segmentation Research of Telecom Operator Organizational Customers Based on Nested-approach (BUPT, Beijing 2014).

[7] SUN Wei, LIN Zhenhui and SHU Huaying: The Method Discussion of Telecom Operators Customer Management in Whole Lifecycle, Mobile Communications Vol.29, 2(2005), p.107-109.

[8] LIN Qixin: Telecom Enterprise Marketing Strategy Based on Customer Lifecycle, Straits Science, 4(2006), p.55-56.

[9] SHU Huaying and QI Jiayin: Lifecycle Management Telecom Customer, BUPT Publications (2004).

[10] WANG Jing: Marketing Segmentation in the Life Cycle of Mobile Communication (BUPT, Beijing 2006).

[11] ZHAO Wanjing and QI Jiayin: The Design of Value Assessment System of Organizational Customer, Value Engineering, Vol.31,2(2012).

[12] LIAO Ying: A Segmentation Research of Bank Individual Customers Based on Customer Value and Customer Stability (HIT, Harbin 2006).

[13] Richard N. Cardozo: Situational Segmentation of Industrial Market, European Journal of Marketing, Vol.14, 5(2007), p.264-276.

[14] GUO Liang, ZHENG Feng: Telecom Operator Organizational Customers Value Assessment and Segmentation Research, Gansu Science and Technology, Vol.22, 12(2006), p.118-120.

[15] LV Zhiguo, JIN Yongsheng, Group Customer Value Evaluation System Design and Marketing Strategies Match, China New Telecommunications, 18(2007), p.46-49.

[16] SU Feng: Customer Value Evaluation Model of China Mobile (NUPT, Beijing 2009).

[17] HANG Weihua and ZHAO Mingjun: The Influence of Undimensionalization on the Reliability of Comprehensive Evaluation Results and an Empirical Analysis, Statistics \& Information Forum, Vol.20, 3(2005). 